\title{
KATP-Associated Hyperinsulinism
}

National Cancer Institute

\section{Source}

National Cancer Institute. KATP-Associated Hyperinsulinism. NCI Thesaurus. Code C131842.

Hyperinsulinism caused by non-functional beta-cell AT P-sensitive potassium channels due to inactivating mutation(s) in either the $\mathrm{ABCC} 8$ or KCNJ11 gene. 